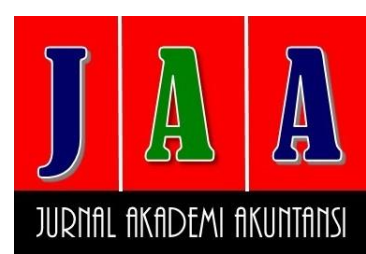

Website:

ejournal.umm.ac.id/index.php/jaa

Afiliasi:

1,2Fakultas Ekonomi, Universitas Internasional Batam, Batam, Indonesia

*Correspondence:

supriyanto.lim@uib.ac.id

DOI: $10.22219 /$ jaa.v4i2.18181

Sitasi:

Supriyanto, \& Hendri, J. (2021). Analisis Pengaruh Tata Kelola Perusahaan Dan Struktur Modal Terhadap Kinerja Perseroan. Jurnal Akademi Akuntansi, 4(2), 246-269.

Proses Artikel

Diajukan:

25 September 2021

Direviu:

30 September 2021

Direvisi:

25 November 2021

Diterima:

26 November 2021

Diterbitkan:

30 November 2021

\author{
Alamat Kantor: \\ Jurusan Akuntansi Universitas \\ Muhammadiyah Malang \\ Gedung Kuliah Bersama 2 \\ Lantai 3. \\ Jalan Raya Tlogomas 246, \\ Malang, Jawa Timur, \\ Indonesia
}

P-ISSN: 2715-1964

E-ISSN: 2654-8321
Tipe Artikel: Paper Penelitian

\section{ANALISIS PENGARUH TATA KELOLA PERUSAHAAN DAN STRUKTUR MODAL TERHADAP KINERJA PERSEROAN Supriyanto $^{1 *}$, Jhoni Hendri ${ }^{2}$}

\section{ABSTRACT}

This paper aims to examine the company's performance problems as measured by book or market value by analyzing the proportion of executive directors, proportion of independent directors, board size, female directors, audit committee meetings, institutional investors, and the company's capital structure. This study uses the company's assets and capital as control variables. The sample of this paper consists of 382 companies excluding the financial sector listed on the Indonesia Stock Exchange from 2016 to 2020. The study used purposive sampling techniques in collecting the research data. Data is processed using multiple regression methods with SPSS and Eviews statistical applications. The results showed that executive directors, independent directors, female directors, audit committee meetings, and institutional investors had no significant effect on ROA or Tobin's $Q$. While the board size proved to have a positive relationship to Tobin's $Q$ but not significantly related to ROA. On the other hand, the capital structure proved to be negatively associated with ROA but significantly positively related to Tobin's $Q$. Limitations on the study were the sample of 41 companies that were not used due to the incomplete annual and financial reports and bankruptcy.

KEYWORDS: Capital Structure; Company Performance; Corporate Governance.

\section{ABSTRAK}

Penelitian ini bertujuan untuk mengkaji permasalahan kinerja perseroan yang diukur dengan nilai buku maupun pasar dengan analisis proporsi direktur eksekutif, proporsi direktur independen, ukuran dewan, direktur wanita, rapat komite audit, investor institusional, dan struktur modal perseroan. Penelitian ini menggunakan aset dan modal perseroan sebagai variabel kontrol. Sampel penelitian ini terdiri dari 382 perusahaan diluar sektor keuangan yang terdaftar di Bursa Efek Indonesia dari tahun 2016 hingga 2020. Dalam mengumpulkan data, penelitian ini menggunakan teknik purposive sampling. Pengolahan data menggunakan metode regresi berganda mengunakan aplikasi statistika SPSS dan Eviews. Hasil penelitian menunjukkan bahwa direktur eksekutif, direktur independen, direktur wanita, rapat komite audit, dan investor institusional tidak memiliki pengaruh signifikan terhadap ROA maupun Tobin's Q. Sedangkan ukuran dewan terbukti memiliki hubungan yang positif terhadap Tobin's Q tetapi tidak berhubungan signifikan dengan ROA. Di sisi lain, struktur modal terbukti berhubungan negatif terhadap ROA tetapi berhubungan signifikan positif terhadap Tobin's Q. Keterbatasan pada penelitian ini terbatas pada sampel yang terdiri atas 41 perusahaan yang dikeluarkan karena laporan tahunan dan keuangan yang belum dipublikasi atau tidak lengkap serta telah pailit.

(C) 2021 jaa. This is an open access article under the CC BY SA license (https://creativecommons.org/licenses/by-sa/4.0/) http://ejournal.umm.ac.id/index.php/jaa 


\section{PENDAHULUAN}

Tata kelola perusahaan dan struktur modal dianggap sebagai faktor penting untuk meningkatkan kesejahteraan pemegang saham. Setiap perseroan yang memiliki tata kelola sehat menjadi indikator bahwa akan meraih kembali uang atau modal yang diinvestasikan dengan tingkat pengembalian investasi yang optimal sedangkan struktur modal yang baik adalah salah satu media yang dapat meminimalkan risiko dan kemungkinan kebangkrutan (Ahmed et al., 2019).

Tata kelola perusahaan yang baik sangat dibutuhkan guna meningkatkan nilai dari perseroan di mata investor serta mengurangi risiko masalah keagenan. Tetapi di sisi lain, pengelolaan struktur modal yang buruk sehingga menimbulkan nilai utang perseroan yang tinggi, membuat nilai perseroan itu sendiri menjadi turun karena semakin tingginya risiko bangkrut (Ganiyu et al., 2018). Dengan kata lain, tata kelola yang baik membantu perseroan untuk menghindari risiko kebangkrutan, kerugian besar dan membantu meningkatkan akuntabilitas perseroan itu sendiri (Ahmed et al., 2019).

Pada Tahun 2015, Ito Warsito (Direktur Utama Bursa Efek Indonesia) mengakui tingkat tata kelola perusahaan di Indonesia masih belum sesuai dengan ekspektasi, walaupun terus mengalami perbaikan. Salah satu contoh nyata yang dapat langsung diamati adalah situs perseroan yang belum disajikan dalam bahasa inggris dan keterbukaan informasi yang belum begitu spesifik (Bisnis, 2015). Hal yang sama juga dilansir dalam Liputan6 (2018) yang menyatakan bahwa penerapan tata kelola perusahaan di Indonesia masih tertinggal dibandingkan sejumlah negara ASEAN lainnya seperti yang diakui oleh Sigit Pramono selaku pimpinan di Indonesian Institute for Corporate Directorship (IICD). Rendahnya tingkat tata kelola perusahaan di Indonesia tidak hanya dapat berdampak kepada investor yang ingin melakukan investasi di Indonesia, melainkan juga mencerminkan kinerja perseroan di Indonesia yang berpotensi terhambat. Dengan kata lain, hal ini mempengaruhi kinerja dari perseroan di Indonesia dan memudarkan kepercayaan investor terhadap pengembalian dari penanaman investasi pada perseroan tersebut (Veno, 2015). Beberapa kasus-kasus korupsi yang diakibatkan oleh tata kelola perusahaan yang buruk seperti kasus Bank Century, Pelindo II, dan Proyek Hambalang seperti yang dilansir di Tribunnews (2020) menyadarkan pemerintah untuk meningkatkan tata kelola perusahaan di Badan Usaha Milik Negara ( $\underline{\mathrm{CNN}, 2019})$. BUMN harus mendorong tata kelola perusahaan yang baik pada perseroannya sesuai dengan keputusan Menteri BUMN No. PER-01/MBU/2011 (Yuanjaya, 2019).

Beberapa kasus yang terjadi juga menunjukkan struktur modal mengambil peran yang penting dengan kinerja perseroan. Kasus ini seperti yang terjadi pada PT. Sri Rejeki Isman, Tbk. Berdasarkan berita yang dilansir oleh Kontan, perseroan ini mencatatkan peningkatan yang signifikan pada utangnya di tahun 2020 Rasio kas perseroan tersebut sendiri menyentuh 47\% alias dibawah 100\%. Rasio kas menunjukkan likuiditas atau kemampuan

JA perusahaan membayar kewajiban jangka pendeknya menggunakan kas perusahaan. Rasio 47\% menunjukkan PT. Sri Rejeki Isman, Tbk. hanya dapat melunasi 47\% utangnya

4.2 menggunakan kas perusahaan tersebut (Birken \& Curry, 2021). Demikian risiko likuiditas meningkat seiring struktur modal yang semakin ekstrim. Hal ini menyebabkan peringkat kredit PT. Sri Rejeki Isman, Tbk dipangkas beberapa Lembaga pemeringkat internasional 
(Qolbi, 2021). Salah satu Lembaga pemeringkat tersebut adalah Fitch Ratings yang menurunkan peringkat PT. Sri Rejeki Isman, Tbk dari B- menjadi CCC- pada bulan April 2021 (Wareza, 2021).

Kasus-kasus diatas menunjukkan penelitian layak untuk segera dilakukan. Beberapa pihak yang membutuhkan mungkin akan dapat menemukan hasil penelitian ini berguna dan dapat dimanfaatkan. Studi ini sendiri merupakan replikasi dari penelitian Farhan Ahmed, Suman Talreja, dan Muhammad Kashif pada Tahun 2018. Perbedaan dan keunikan antara penelitian tersebut dengan penelitian ini terdapat pada beberapa variabel yang ditambah seperti direktur eksekutif, direktur independen, direktur wanita, dan investor institusional sebagai variabel independen untuk mendukung teori keagenan. Keempat variabel tersebut dianggap sebagai proksi tata kelola perusahaan yang cukup kuat berdasarkan penelitian Bashir et al. (2020). Variabel direktur eksekutif dan direktur independen menunjukkan variabel independen ukuran dewan yang dipecah menjadi porsi masing-masing direksi dalam anggota dewan. Porsi tersebut beserta keberadaan direktur wanita dan investor institusional dapat mempengaruhi proses pengambilan keputusan (PeiZhi \& Ramzan, 2020). Demikian tata kelola perusahaan yang diteliti dapat digambarkan menjadi lebih lengkap pada penelitian ini. Untuk menyetarakan sampel penelitian, variabel kontrol ditambahkan, yaitu aset perseroan dan modal perseroan.

Berdasarkan perbedaan pengaruh yang terjadi karena perbedaan variabel dan juga uraian masalah diatas penelitian ini diberi judul "Tata Kelola Perusahaan, Struktur Modal, dan Kinerja Perseroan: Bukti Empiris dari Perseroan Non Finansial di Bursa Efek Indonesia”. Hasil penelitian terdahulu yang berbeda-beda menunjukkan adanya research gap yang kemudian diteliti lebih lanjut pada penelitian ini. Penelitian ini diharapkan dapat berkontribusi bagi perseroan mengenai informasi-informasi pengaruh penerapan tata kelola perusahaan yang baik dan struktur modal terhadap kinerja perseroan sehingga dapat dijadikan pedoman. Hasil penelitian juga diharapkan dapat berperan sebagai media yang dapat membantu investor mengambil keputusan investasi sehingga dapat lebih bijaksana serta digunakan sebagai referensi pendukung dalam karya ilmiah kedepannya.

\section{LANDASAN TEORI DAN PENGEMBANGAN HIPOTESIS}

\section{Teori Keagenan}

Teori keagenan timbul karena dilatarbelakangi oleh pemisahan antara pemilik perseroan dan pengelola perseroan yang dianggap dapat menimbulkan masalah atau perbedaan kepentingan (Hundal et al., 2020). Konflik keagenan ini dapat menimbulkan biaya keagenan yang dapat merugikan pengelola perseroan dan mengurangi tingkat pengembalian pemegang saham (Zeitu, 2014). Karena itu pula skema tata kelola perusahaan digunakan sebagai kerangka untuk membangun lingkungan kerja yang transparan, jujur, dan akuntabel. Tata kelola perusahaan merupakan media penting yang digunakan untuk mengurangi konflik keagenan tersebut sehingga meminimalisasi kerugian yang mungkin timbul (Detthamrong et al., 2017). Studi PeiZhi \& Ramzan (2020) juga memberikan bukti bahwa masalah keagenan mempengaruhi keputusan pengelola perseroan dalam mengelola struktur modal. Hal tersebut juga dapat secara langsung mempengaruhi kinerja perseroan melalui biaya keagenan. Demikian, pengelola harus mengurangi biaya keagenan untuk meningkatkan kinerja perseroan dan hal ini hanya dapat dicapai melalui struktur tata kelola perusahaan yang baik. 


\section{Kinerja Perusahaan}

Veno (2015) dalam penelitiannya menyatakan kinerja merupakan hasil dari kegiatan tertentu yang dicapai dan dilakukan untuk menjangkau tujuan perseroan serta diukur dengan standar yang ada. Kinerja perseroan dinilai sekaligus untuk mengkaji efektivitas dari operasional perseroan. Pada saat yang bersamaan, kinerja perseroan juga dapat dilihat dalam perspektif yang lebih luas, yaitu sebagai bagian dari perkembangan bisnis suatu perseroan. Perkembangan bisnis dari suatu perseroan itu sendiri mencerminkan kinerja perseroan dan menilai efektifitas dalam perseroan (UKEssays, 2018).

Tingkat dari pertumbuhan dan keberhasilan sebuah perseroan dapat tercermin dari tingkat kinerja perseroan tersebut. Pengukuran kinerja perseroan ini telah menarik banyak perhatian akademisi dan praktisi bisnis. Hal ini dikarenakan pengukuran kinerja tersebut membantu orang-orang yang berkepentingan untuk mengevaluasi pertumbuhan bisnis dan daya saing sebuah perseroan (Ganiyu et al., 2018). Dalam buku yang diterbitkan oleh IAI Global (2016), dinyatakan bahwa pengukuran kinerja perseroan tidak semata-mata hanya berdasarkan efisiensi perseroan itu sendiri tetapi juga tergantung pada pangsa pasar dari perseroan tersebut.

\section{Penelitian Terdahulu}

Penelitian mengenai pengaruh tata kelola perusahaan dan struktur modal terhadap kinerja perseroan telah banyak diteliti oleh peneliti sebelumnya. Penelitian terdahulu yang dilakukan memiliki pengukuran yang berbeda-beda seperti ukuran dewan, rapat komite audit, direktur eksekutif, independensi dewan, akuntabilitas dewan, transparansi dan pengungkapan, kepemilikan dewan, ukuran dewan direksi, dan masih banyak lagi. Detthamrong et al. (2017) menggunakan ukuran dewan, independensi dewan, dualitas, komite audit, jabatan direktur perempuan, konsentrasi kepemilikan, dan reputasi audit sebagai pengukuran tata kelola perusahaan. Penelitian ini menggunakan metode kuantitatif dalam pengumpulan datanya karena dirasa lebih cocok untuk menjawab pertanyaan penelitian secara empiris. Metode regresi Ordinary Least Squares (OLS) digunakan dalam penelitian ini untuk mendeteksi pengaruh tata kelola perusahaan terhadap kinerja perseroan.

Dalam penelitian Mohamed et al. (2013) yang bertujuan untuk meneliti dampak tata kelola perusahaan yang tercatat di Bursa Efek Mesir terhadap kinerja perseroan, beberapa proksi digunakan sebagai pengukuran kinerja keuangan. Variabel independen yang digunakan terdiri dari komite audit, kepemilikan institusi, kepemilikan direksi, konsentrasi kepemilikan, dualitas, ukuran dewan, dan independensi dewan. Ada pula variabel kontrol seperti umur perseroan, tipe industri, ukuran perseroan, dan tingkat leverage. Beberapa penelitian terdahulu yang juga meneliti hubungan tata kelola perusahaan terhadap kinerja perseroan adalah seperti Al-ahdal et al. (2020), Vo \& Nguyen (2014), Ahmed \& Hamdan (2015), Nazir et al. (2018), serta Habib (2016).

Selanjutnya penelitian Darko et al. (2016) menganalisa hubungan yang ada antara tata kelola perusahaan kepada kinerja perseroan yang terdaftar di Bursa Efek Ghana. Penelitian ini menggunakan sampel 20 perseroan dari Tahun 2008 sampai 2012. Data pada penelitian ini diuji menggunakan regresi panel dan Analysis of Variance (ANOVA) untuk menelusuri pengaruh tata kelola perusahaan kepada kinerja perseroan. Tata kelola perusahaan diukur 4.2 menggunakan ukuran dewan, independensi dewan, jenis kelamin dewan, 20 pemegang saham terbaik, kepemilikan negara, ukuran komite audit, dan rapat audit, sedangkan kinerja perseroan diukur menggunakan ROA, ROE, NPM, dan Tobin's Q. Penelitian ini kemudian dikembangkan oleh PeiZhi \& Ramzan (2020), Ullah, Nouman, et al. (2019), serta Ahmed et 
al. (2019) dengan menambahan struktur modal sebagai variabel independen yang juga dapat mempengaruhi kinerja perseroan.

\section{Pengembangan Hipotesis}

Perseroan membutuhkan orang yang dapat menjalankan operasional dan mengambil keputusan yang biasanya disebut sebagai seorang direktur perseroan. Direktur eksekutif merupakan direktur yang diberikan sebagian kekuasaan dan izin dari dewan direksi untuk bertindak dan mengambil keputusan sehari-hari (PeiZhi \& Ramzan, 2020). Direktur eksekutif juga ditugaskan untuk melindungi aset dan kepentingan pemilik perseroan sebagai bagian dari tata kelola perusahaan (Shakir, 2008). Direktur eksekutif juga dikenal sebagai direktur internal dan memiliki informasi yang lebih rinci dibandingkan dengan direktur eksternal. Demikian apabila direktur eksekutif menggunakan peran tersebut dengan efektif dalam pengawasan melalui informasi yang tepat, tata kelola perusahaan dapat ditingkatkan yang kemudian juga akan menunjukkan peningkatan pada kinerja perseroan (Anderson \& Reeb, 2003).

Dalam penelitian PeiZhi \& Ramzan (2020), direktur eksekutif dinyatakan berhubungan positif terhadap kinerja perseroan. Shakir (2008) dalam penelitiannya mengkaji hubungan antara ukuran dewan, persentase eksekutif dan kinerja perseroan properti yang terdaftar di Malaysia. Penelitian tersebut menyatakan hasil yang berbeda dimana direktur eksekutif dinyatakan berhubungan negatif terhadap kinerja perseroan. Sesuai dengan teori keagenan, direktur eksekutif dianggap dapat menyebabkan kebenturan kepentingan dengan pemegang saham. Demikian berdasarkan beberapa hasil penelitian terdahulu, maka dapat dibentuk hipotesis pertama sebagai berikut.

\section{$\boldsymbol{H}_{1}$ : Direktur Eksekutif berpengaruh negatif terhadap kinerja perseroan.}

Direktur independen adalah seseorang dalam perseroan yang bukan merupakan karyawan dan tidak memiliki hubungan yang material terhadap perusahaan (Brown \& Caylor, 2006). Direktur independen ini juga penting untuk perkembangan keuangan perusahaan secara berkelanjutan (Bassem, 2009). Penelitian PeiZhi \& Ramzan (2020) menyatakan keberadaan direktur independen dalam dewan direksi lebih baik karena direktur independen memiliki peran untuk memastikan semua peraturan telah ditaati dan melindungi kepentingan pemegang saham. Prinsip dan kode etik tata kelola perusahaan juga menekankan komposisi anggota dewan yang seimbang terdiri dari direktur independen. Direktur independen sendiri ditunjuk oleh perseroan untuk memantau kinerja direktur eksekutif dan manajemen (Fuzi et al., 2016).

Variabel ini digunakan dalam beberapa penelitian terdahulu seperti penelitian Borlea et al. (2017). Penelitian yang menginvestigasi hubungan karakteristik dewan terhadap kinerja perseroan di Rumania ini menyatakan bahwa direktur independen berhubungan negatif terhadap kinerja perseroan. Penelitian Veno (2015), Noreen et al. (2018), dan Ullah, Afgan, et al. (2019) juga menyatakan hasil yang sama.

Di sisi lain penelitian lain menyatakan direktur independen berhubungan positif kepada kinerja perseroan. Penelitian dari PeiZhi \& Ramzan (2020), Nyamongo \& Temesgen (2013), Kyere \& Ausloos (2020), serta Pucheta-Martínez \& Gallego-Álvarez (2020) juga menggunakan independensi dewan direksi sebagai variabel independen. Hasil dari kelima penelitian tersebut menyatakan hubungan yang ada di antara direktur independen dengan kinerja perseroan adalah hubungan positif. Hasil tersebut sejalan dengan teori keagenan dimana keberadaan direktur independen menghasilkan kontribusi yang positif bagi perusahaan (PeiZhi \& Ramzan, 2020). Berdasarkan pembuktian dari beberapa penelitian 
sebelumnya, dapat disimpulkan hipotesis kedua sebagai berikut ini.

\section{$\boldsymbol{H}_{2}$ : Direktur Independen berpengaruh positif terhadap kinerja perseroan.}

Dalam Peraturan Otoritas Jasa Keuangan Nomor 33/ POJK. 04/2014 Tentang Direksi Dan Dewan Komisaris Emiten Atau Perseroan Publik (2014), disebutkan direksi adalah hal yang berperan penting atau inti dalam perseroan. Posisi ini memiliki wewenang dan memiliki tanggung jawab untuk pengurusan dan perwakilan perseroan. Dewan direksi sendiri merupakan sejumlah individu yang ditugaskan untuk mengelola dan memimpin perseroan (Masitoh \& Hidayah, 2018). Di sisi lain, ukuran dewan membahas mengenai jumlah dari anggota direksi yang dibentuk dalam suatu perseroan. Dalam penelitian PeiZhi \& Ramzan (2020), ukuran dewan memberikan pengaruh positif kepada kinerja perseroan. Hal ini berarti semakin besar ukuran dewan, kinerja perseroan akan meningkat pula.

Penelitian Narwal \& Jindal (2015), Ahmed et al. (2019), Rehman \& Sadat (2013), Akbar et al. (2019), serta Darko et al. (2016) mengemukakan bahwa ukuran dewan berhubungan negatif terhadap kinerja perseroan. Hal serupa juga ditujukkan dalam penelitian Azeez (2015). Penelitian tersebut mengindikasi ukuran dewan yang kecil dapat meningkatkan kinerja perseroan. Hubungan yang negatif ini disebabkan oleh kecilnya ukuran dewan mengakibatkan manajemen diawasi dengan ketat sehingga operasional perseroan menjadi lebih produktif dan meningkatkan kinerja perseroan.

Di sisi lain Veno (2015) menyatakan bahwa ukuran dewan berpengaruh signifikan positif terhadap kinerja perseroan. Penelitian ini menyimpulkan bahwa semakin besar ukuran dewan direksi dalam perseroan, kinerja perseroan juga akan meningkat. Konsisten dengan teori keagenan, ukuran dewan yang besar dapat meningkatkan fungsi pengawasan sehingga tata kelola perusahaan yang baik dapat tercapai. Hal ini konsisten dengan penelitian PeiZhi \& Ramzan (2020), Habib (2016), Mohamed et al. (2013), dan Noreen et al. (2018). Berikut ini adalah hipotesis penelitian ketiga yang dibentuk berdasarkan hasil pembuktian penelitian-penelitian sebelumnya.

\section{$\boldsymbol{H}_{3}$ : Ukuran Dewan berpengaruh positif terhadap kinerja perseroan.}

Keberagaman gender di dalam dewan direksi dianggap sebagai indikasi positif. Hal ini dikarenakan direktur wanita dapat meningkatkan efisiensi dan independensi dewan direksi perseroan. Oleh karena itu, direktur wanita dinyatakan dapat memberi dampak yang positif terhadap kinerja perusahaan karena sikap positif dan proaktif dari direktur wanita itu sendiri Terjesen et al. (2016). Kehadiran perempuan di dewan direksi juga vital untuk implementasi aturan, kebijakan, dan peraturan. Karena itu pula kehadiran direktur wanita juga memberikan perubahan positif dalam pendapatan perseroan (Triana \& Asri, 2017).

Direktur wanita berpengaruh negatif terhadap kinerja perseroan dinyatakan dalam beberapa penelitian. Hubungan yang negatif tersebut dapat ditemukan dalam penelitian (Saleh \& Islam, 2020). Penelitian tersebut meneliti hubungan antara karakteristik dewan terhadap kinerja perseroan yang terdaftar di Palestina. Hubungan direktur wanita dan kinerja perusahaan dinyatakan negatif pada penelitian tersebut. Di sisi lain, Detthamrong et al. (2017) dalam penelitiannya menyatakan kinerja perseroan tidak dipengaruhi secara signifikan oleh direktur wanita.

JAA Hasil berbeda ditemukan dalam penelitian PeiZhi \& Ramzan (2020). Penelitian tersebut menunjukkan anggota dewan yang dilantik dengan cermat (direktur wanita) memberikan pengaruh positif terhadap kinerja perseroan berdasarkan teori keagenan. Penelitian Habib (2016) yang dilakukan untuk mengukur hubungan antara tata kelola perusahaan dan kinerja perseroan yang tercatat di Bursa Efek Dhaka juga menunjukkan analisis yang sama. 
Hubungan positif antara kedua variabel juga ditemukan dalam hasil penelitian PuchetaMartínez \& Gallego-Álvarez (2020) serta Saha \& Kabra (2015). Keberadaan direktur wanita juga memiliki beberapa keunggulan dibandingkan dengan laki-laki. Direktur wanita dianggap lebih berhati-hati dalam mengambil keputusan sehingga lebih konservatif. Direktur wanita juga memprioritaskan kebijakan yang berorientasi pada etika (Ramadan et al., 2021). Berdasarkan pembuktian beberapa penelitian yang telah dirincikan diatas, dapat disimpulkan hipotesis keempat sebagai berikut.

\section{$\boldsymbol{H}_{4}$ : Direktur Wanita berpengaruh positif terbadap kinerja perseroan.}

Komite audit adalah komponen yang penting dalam suatu perseroan. Komite audit mencegah adanya kecurangan dalam perseroan. Atas dasar tersebut, anggota komite audit sendiri harus berisi orang yang memiliki pengalaman di bidang tersebut (Warrad \& Khaddam, 2020). Dewan komisaris merupakan pihak yang biasanya membentuk komite ini untuk bekerja sama dalam melaksanakan tugas dan fungsinya. Peran komite audit dalam suatu perseroan sendiri semakin penting karena semakin tingginya tuntutan atas transparansi dan kredibilitas serta integritas dari suatu perseroan (Veno, 2015). Mohamed et al. (2013) menyatakan komite audit berfungsi untuk mengawasi manajemen perseroan dan auditor internal maupun eksternal untuk melindungi kepentingan para pemegang saham. Dalam penelitiannya rapat komite audit berhubungan negatif dengan kinerja perseroan. Pernyataan ini konsisten dengan penelitian yang lain yang juga menyatakan hal yang sama, diantaranya adalah penelitian Ahmed et al. (2019), Noreen et al. (2018), dan Jamal \& Mahmoood (2018).

Penelitian Jamal \& Mahmoood (2018) serta Noreen et al. (2018) menunjukkan adanya hubungan negatif antara rapat komite audit dan kinerja perseroan apabila diukur menggunakan ROE. Sedangkan penelitian dalam penelitian Ahmed et al. (2019), hubungan negatif antara rapat komite audit dan kinerja perseroan ditemukan dengan menggunakan pengukuran ROA. Hal ini menunjukkan keberadaan komite audit menurunkan kinerja perseroan.

Hal yang berbeda ditunjukkan dalam penelitian PeiZhi \& Ramzan (2020) yang menyatakan rapat komite audit berhubungan positif dengan kinerja perseroan. Hasil penelitian tersebut mengemukakan pengawasan dari komite audit dapat meningkatkan kinerja perseroan. Hasil yang serupa juga ditemukan dalam penelitian Veno (2015) yang menunjukkan rapat komite audit dapat berhubungan positif kepada kinerja perseroan apabila diukur menggunakan ROE. Berdasarkan uraian tersebut, maka dapat disimpulkan hipotesis kelima sebagai berikut.

\section{$\boldsymbol{H}_{5}:$ Rapat Komite Audit berpengarub negatif terhadap kinerja perseroan.}

Investor institusional adalah investor yang mengumpulkan dana dari investor individual yang kemudian digunakan untuk membeli sekuritas dan investasi lainnya. Investor institusional memiliki hubungan atas investasi yang ditanamkan dan memiliki pengaruh dalam pengambilan keputusan perseroan (David et al., 1989). Selama beberapa tahun terakhir, investor institusional menjadi bagian yang penting untuk meningkatkan kinerja melalui pengawasan yang aktif dan juga berperan dalam meningkatkan nilai pemegang saham melalui menarik lebih banyak investasi (Ryff, 2017). Penelitian Dewi \& Gustyana (2020) menyatakan perseroan dengan porsi investor institusional yang tinggi menyebabkan manajemen perseroan cenderung lebih diawas oleh investor itu sendiri.

Bertolak belakang dengan argumen tersebut, beberapa penelitian menunjukkan pengaruh investor institusional terhadap kinerja perseroan bersifat negatif. Penelitian yang dilakukan 
oleh Zeitun (2014) untuk menginvestigasi efek struktur dan konsentrasi kepemilikan terhadap kinerja 203 perseroan dari 5 negara yang tergabung dalam Dewan Kerjasama untuk Negara Arab di Teluk menunjukkan investor insitusional berpengaruh negatif terhadap kinerja perusahaan. Hasil yang konsisten ditunjukkan dalam penelitian Chabachib et al. (2020) yang juga menunjukkan adanya hubungan atau pengaruh negatif anatra investor institusional terhadap kinerja perseroan.

Berdasarkan argumen sebelumnya, beberapa penelitian telah menunjukkan hubungan positif dari investor institusional pada kinerja perseroan. Penelitian tersebut menyatakan bahwa perilaku investor intitusional yang aktif lebih efisien dan hubungannya dengan kinerja perseroan adalah bilateral. Penelitian yang dilakukan oleh PeiZhi \& Ramzan (2020), Ullah, Afgan, et al. (2019), Akbar et al. (2019), Mohamed et al. (2013), Bashir et al. (2020), dan Nazir et al. (2018) juga menunjukkan adanya hubungan positif antara investor institusional terhadap kinerja perseroan. Demikian hipotesis keenam yang disimpulkan berdasarkan hasil-hasil penelitan terdahulu yang telah dijelaskan diatas.

$\boldsymbol{H}_{6}$ : Investor Institusional berpengaruh positif terhadap kinerja perseroan.

Struktur modal adalah kombinasi antara utang perseroan baik utang jangka panjang maupun jangka pendek, dengan ekuitas. Kombinasi ini juga dapat memperlihatkan bagaimana perseroan membiayai operasional dan pertumbuhannya secara keseluruhan melalui sumber dana yang berbeda ( $\underline{\text { San et al., 2011) }}$. Baik atau buruknya struktur modal suatu perseroan dapat mempengaruhi posisi keuangan perseroan tersebut ( Naelufar, 2020). Menurut Kinsman dan Newman (1999) seperti yang dikutip dalam penelitian Abata \& Migiro (2019), menyebutkan bahwa keputusan struktur modal memiliki hubungan yang signifikan terhadap kinerja perseroan.

Ahmed \& Bhuyan (2020) dalam penelitiannya menunjukkan struktur modal yang diukur menggunakan leverage berhubungan signifikan negatif terhadap kinerja perseroan dengan ROA sebagai pengukurannya. Penggunaan utang yang berlebihan oleh perseroan dapat menurunkan kualitas laba dari suatu perseroan (Utami, 2020). Hubungan negatif antara struktur modal dengan kinerja perseroan juga ditemukan dalam beberapa penelitian lainnya. Hubungan yang sama tersebut dapat ditemukan dalam penelitian Akingunola et al. (2018), Muhammad et al. (2014), serta Kipesha \& James (2014).

Konsisten dengan penelitian sebelumnya, hasil yang sama dikemukakan dalam penelitian Abata et al. (2017) serta Nguyen \& Nguyen (2020). Penelitian dengan objek perseroan yang tercatat di Bursa Efek Vietnam tersebut menyatakan struktur modal berhubungan negatif dengan kinerja perseroan. Penelitian Abdur Rouf (2015) serta Kipesha \& James (2014) juga menunjukkan hasil yang sama. Studi PeiZhi \& Ramzan (2020) sendiri menyatakan bahwa masalah keagenan mempengaruhi keputusan pengelola perseroan dalam mengelola struktur modal. Berdasarkan uraian hasil penelitian sebelumnya, maka dapat dibentuk hipotesis ketujuh sebagai berikut.

$\boldsymbol{H}_{7}$ : Struktur Modal berpengarub negatif terhadap kinerja perseroan.

Berdasarkan pembahasan yang telah dipaparkan diatas, maka hubungan antar variabel dependen dengan independen dalam penelitian ini dapat disusun dalam sebuah model

JAA penelitian. Model penelitian dapat dilihat pada gambar dibawah ini. 


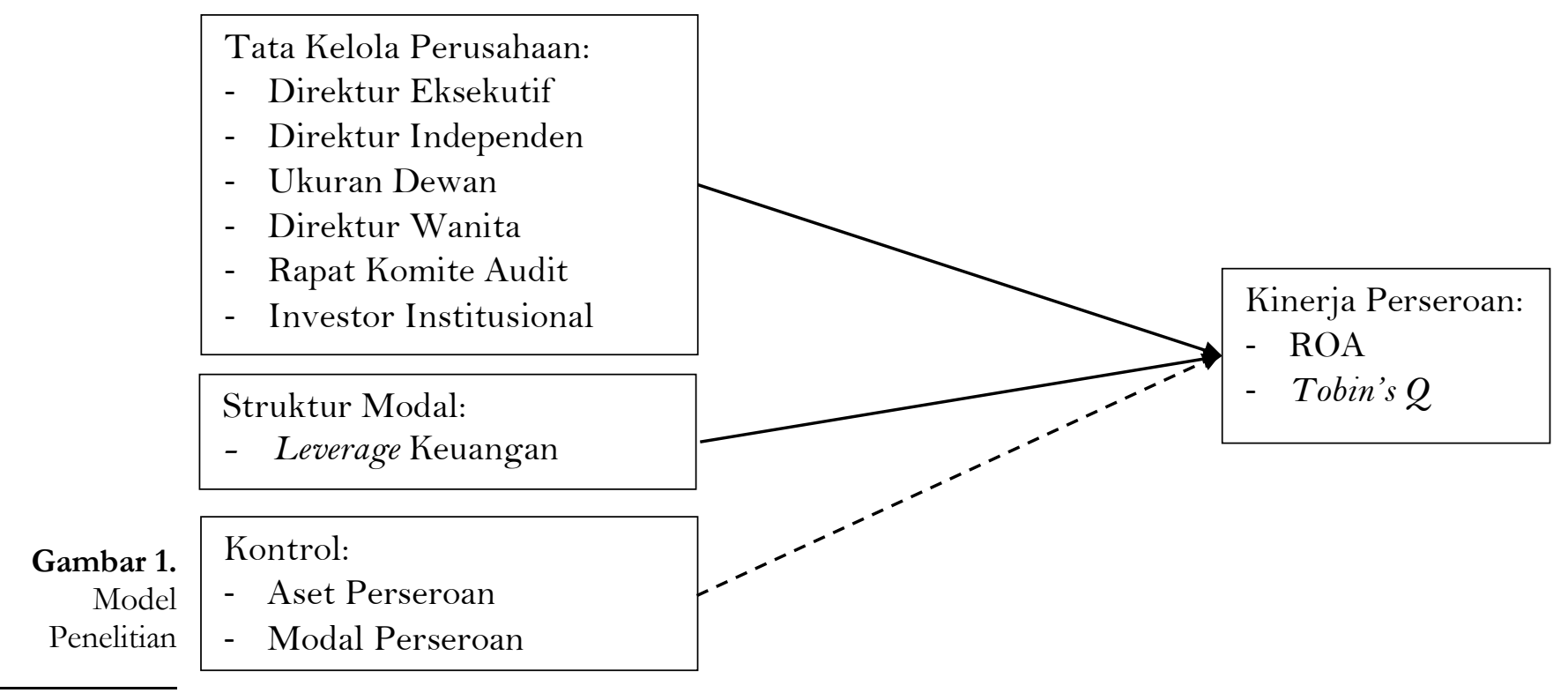

Sumber: Data diolah

\section{METODE}

Sesuai dengan tujuan dari studi ini, penelitian ini dilakukan melalui pengembangan dari model penelitian terdahulu. Penelitian ini tergolong penelitian kuantitatif berdasarkan jenis data yang digunakan (Sinambela, 2020). Studi ini juga menggunakan jenis data panel. Data diambil dengan periode 5 tahun supaya dapat menggambarkan hubungan antar variabel yang lebih konkret yaitu dari tahun 2016 hingga 2020. Populasi dari studi ini adalah perseroan non finansial yang tercatat dalam Bursa Efek Indonesia (BEI). Data yang diperlukan sebagai pengukuran variabel studi ini dapat ditemukan dalam laporan keuangan maupun tahunan perseroan yang dapat diperoleh melalui situs BEI bagian keterbukaan informasi (http://www.idx.co.id) dan situs resmi perseroan.

Perseroan yang bergerak dalam sektor finansial dikecualikan dari sampel dalam penelitian ini. Hal ini untuk mencegah biasnya data yang dikumpulkan karena karakteristik industri finansial yang berbeda dengan industri lain pada umumnya. Selain itu, industri ini sendiri sudah diregulasi dengan baik di Indonesia sehingga tata kelola perusahaan di industri ini pada umumnya sudah cukup baik (Hidayat \& Utama, 2015). Teknik pengumpulan yang digunakan adalah teknik purposive sampling dimana sampel ditentukan berdasarkan karakteristik tertentu sesuai dengan tujuan dilakukannya penelitian ini. Sampel yang digunakan harus memenuhi beberapa syarat dan kriteria, diantaranya adalah perseroan diluar sektor keuangan terdaftar di BEI dan melampirkan laporan tahunan selama 5 periode terakhir yaitu dari tahun 2016 hingga 2020. Perseroan yang digunakan sebagai sampel juga mengungkapkan informasi yang dibutuhkan dalam studi ini dalam hal laporan keuangan maupun tahunan secara jelas dan lengkap.

\section{Definisi dan Pengukuran Variabel}

\section{Kinerja Perseroan}

Kinerja perseroan merupakan hasil atau pencapaian yang diperoleh oleh manajemen, ekonomi, dan pemasaran suatu perseroan dalam persaingan yang ada dengan efisiensi dan efektivitas kepada perseroan itu sendiri (Taouab \& Issor, 2019). Penelitian ini menggunakan 2 proksi sebagai pengukuran dari kinerja perseroan. Pengukuran pertama adalah ROA yang digunakan untuk mengukur kinerja perseroan berbasis nilai buku. Sedangkan pengukuran 
yang kedua menggunakan Tobin's $Q$ yaitu sebagai proksi dari performa perseroan berdasarkan nilai pasar. Penelitian Nawaz \& Ahmad (2017) serta Hakim \& Naelufar (2020) menyebutkan ROA dihitung dengan membagikan laba bersih pada total aset perseroan. Rumus yang digunakan dalam pengukuran Tobin's $\mathrm{Q}$ dalam penelitian ini sama dengan yang digunakan pada penelitian Akbar et al. (2019) serta Aini et al. (2021). Berikut adalah rumus dari ROA dan Tobin's $Q$ sesuai dalam penelitian-peneitian tersebut.

$$
\begin{aligned}
& \text { ROA }=\frac{\text { Laba Bersih }}{\text { Total Aset }} \\
& \text { Tobin's } Q=\frac{\text { Nilai Pasar Ekuitas }+ \text { Nilai Buku Liabilitas }}{\text { Nilai Buku Aset }}
\end{aligned}
$$

\section{Direktur Eksekutif}

Direktur eksekutif atau direktur internal merupakan direktur yang diberikan sebagian kekuasaan dan izin dari dewan komisaris untuk bertindak dan mengambil keputusan seharihari (PeiZhi \& Ramzan, 2020). Menurut Shakir (2008), direktur eksekutif dapat diukur dengan melakukan pembagian antara jumlah direktur eksekutif dalam suatu perseroan dengan jumlah keseluruhan dewan direksi perseroan. Informasi mengenai jumlah direktur eksekutif dapat diperoleh melalui laporan tahunan perseroan.

\section{Direktur Independen}

Direktur independen adalah seseorang dalam perseroan yang bukan merupakan karyawan dan tidak memiliki hubungan yang material terhadap perseroan (PeiZhi \& Ramzan, 2020). Menurut Bashir et al. (2020), direktur independen dapat diukur dengan mengamati persentase dari jumlah direktur independen dalam suatu perseroan terhadap jumlah keseluruhan anggota dewan direksi. Informasi mengenai variabel ini sendiri dapat ditemukan dalam laporan tahunan perseroan.

\section{Ukuran Dewan}

Dewan direksi merupakan sejumlah individu yang ditugaskan untuk mengelola dan memimpin perseroan (Masitoh \& Hidayah, 2018). Informasi ini dapat ditemukan di laporan tahunan pada bagian struktur organisasi perseroan yang tercatat di Bursa Efek Indonesia. Pengukuran variabel ini menggunakan informasi jumlah anggota dewan direksi perseroan (Mohamed et al., 2013).

\section{Direktur Wanita}

Beberapa keyakinan yang sedang berkembang percaya bahwa direktur wanita dapat meningkatkan efektivitas dewan direksi (Detthamrong et al., 2017). Pengukuran yang sama juga digunakan dalam penelitian Pucheta-Martínez \& Gallego-Álvarez (2020) yaitu jumlah direktur wanita yang terdapat dalam dewan direksi. Informasi mengenai jumlah direktur wanita dalam suatu perseroan sendiri dapat diperoleh melalui laporan tahunan yang diterbitkan perseroan.

\section{Rapat Komite Audit}

JAA Mohamed et al. (2013) dalam penelitiannya menyatakan komite audit adalah komite yang dibentuk untuk mengawasi manajemen perseroan dan auditor internal maupun eksternal

4.2 untuk melindungi kepentingan para pemegang saham. Variabel ini dapat diukur menggunakan informasi jumlah rapat komite audit perseroan (Noreen et al,, 2018). Informasi ini juga dapat diakses melalui laporan tahunan perseroan. 


\section{Investor Institusional}

Investor institusional merupakan investor yang menggunakan dana dari investor individual lainnya yang telah dikumpulkan dan kemudian digunakan untuk pembelian sekuritas atau investasi lainnya (David et al., 1989). Data mengenai variabel ini dapat ditemukan dalam laporan perseroan yang diterbitkan setiap tahunnya. Investor institusional dapat diukur dengan mengamati kepemilikan investor institusional (Dewi \& Gustyana, 2020).

\section{Struktur Modal}

Struktur modal adalah kombinasi antara utang perseroan baik utang jangka panjang maupun jangka pandek, dengan ekuitas ( dalam penelitian sama dengan dalam penelitian San et al. (2011) yang diwakili oleh leverage. Leverage diukur menggunakan Debt to Asset Ratio (DAR) yaitu menghitung total aset yang didanai melalui total utang dalam suatu perseroan (Bashir et al., 2020). Tingkat leverage yang tinggi di perseroan mencerminkan potensi kebangkrutan perseroan yang lebih besar (Abata \& Migiro, 2019). Oleh karena itu, penelitian Majid et al. (2020) menyatakan bahwa resiko perseroan akan semakin tinggi seiring dengan tingginya leverage perseroan tersebut. Datadata yang dibutuhkan untuk memenuhi variabel ini dapat ditemukan dalam laporan keuangan perseroan. Variabel ini sendiri dapat dihitung dengan rumus yang sama dalam penelitian Ahmed \& Bhuyan (2020) yaitu sebagai berikut.

$$
D A R=\frac{\text { Total Liabilitas }}{\text { Total Aset }}
$$

\section{Variabel Kontrol}

Jumlah aset dan modal perseroan digunakan sebagai variabel kontrol karena dipercaya dapat mempengaruhi kinerja perseroan (PeiZhi \& Ramzan, 2020). Data mengenai jumlah aset dan modal perseroan sendiri dapat ditemui dalam laporan keuangan maupun laporan tahunan yang diterbitkan perseroan. Variabel ini diukur menggunakan logaritma natural dari jumlah aset dan modal perseroan (Noreen et al., 2018).

\section{HASIL DAN PEMBAHASAN}

\section{Hasil Analisis}

Data sekunder digunakan dalam studi ini apabila dikategorikan berdasarkan sumber perolehannya. Dimana data tersebut merupakan data yang yang telah diolah oleh Bursa Efek Indonesia. Data tersebut juga dikategorikan sebagai data kuantitatif berdasarkan sifatnya. Data yang telah dikumpul dan dianalisis berasal dari laporan tahunan dan laporan keuangan dalam periode tahun 2016 hingga 2020. Berdasarkan waktu pengumpulan, data yang dikumpulkan termasuk data time series.

Data-data yang didapatkan dari laporan tahunan masing-masing perseroan diinput ke dalam kertas kerja berupa spreadsheet di microsoft excel. Aplikasi SPSS 25 digunakan terlebih dahulu untuk melakukan uji outlier. pada tahap selanjutnya, Aplikasi Eviews 10 digunakan untuk melakukan uji hipotesis. Pada Tabel 1 disajikan daftar jumlah perseroan yang digunakan sebagai sampel.

Berdasarkan tabel diatas, dapat dilihat jumlah perseroan yang sudah terdaftar dalam Bursa Efek Indonesia sejak tahun 2016 ada sebanyak 514 perseroan. Selama periode tersebut juga terdapat 91 perseroan dari sektor finansial yang dikeluarkan dari sampel penelitian. Terdapat 32 perseroan yang tidak memenuhi kelengkapan laporan tahunan dan laporan keuangan sehingga tidak dapat digunakan. Serta 9 perusahaan yang tidak melampirkan 
informasi jumlah rapat komite audit dalam laporan tahunannya. Demikian perseroan yang

257 memenuhi kriteria adalah sebanyak 382 perseroan dengan jumlah keseluruhan hingga tahun 2020 mencapai 1.910 data. Setelah melewati pengujian outlier, terdapat 79 data yang tidak melewati tes ini sehingga tersisa 1.831 data yang dapat digunakan sebagai sampel penelitian.

\begin{tabular}{lrll}
\hline \multicolumn{1}{c}{ Keterangan } & \multicolumn{2}{c}{ Jumlah } \\
\hline Perusahaan terdaftar di BEI periode 2016-2020 & 514 & Perusahaan \\
Perusahaan sektor finansial & $-91 \quad$ Perusahaan & \\
Banyak perusahaan yang tidak memenuhi kriteria & & & \\
$\quad$ Belum terbitnya laporan tahunan terbaru & -32 & \\
$\quad$ Tidak adanya lampiran informasi Rapat Komite Audit & -9 & Perusahaan & \multirow{2}{*}{ Tabel 1. } \\
Perusahaan yang memenuhi kriteria & 382 & Perusahaan & $\begin{array}{l}\text { Daftar Jumlah } \\
\text { Perseroan }\end{array}$ \\
Lama tahun penelitian & 5 & Tahun & yang \\
Jumlah data penelitian & 1910 & Data & Dijadikan \\
Banyak data outlier & -79 & Data \\
Data yang layak diteliti & $1831 \quad$ Data & Sampel \\
\hline
\end{tabular}

Statistik Deskriptif

\begin{tabular}{|c|c|c|c|c|c|}
\hline c & $\mathbf{N}$ & Minimum & Maximum & Mean & $\begin{array}{c}\text { Std. } \\
\text { Deviation }\end{array}$ \\
\hline Return on Asset & $\begin{array}{c}183 \\
1\end{array}$ & $-0,51$ & 0,47 & 0,02 & 0,09 \\
\hline Tobin's $Q$ & $\begin{array}{c}183 \\
1\end{array}$ & 0,12 & 25,19 & 1,37 & 1,10 \\
\hline Direktur Eksekutif & $\begin{array}{c}183 \\
1\end{array}$ & 0,25 & 1,00 & 0,84 & 0,15 \\
\hline Direktur Independen & $\begin{array}{c}183 \\
1\end{array}$ & 0,00 & 0,75 & 0,16 & 0,15 \\
\hline Ukuran Dewan & $\begin{array}{c}183 \\
1\end{array}$ & 2,00 & 15,00 & 4,76 & 1,87 \\
\hline Direktur Wanita & $\begin{array}{c}183 \\
1\end{array}$ & 0,00 & 5,00 & 0,63 & 0,84 \\
\hline Rapat Komite Audit & $\begin{array}{c}183 \\
1\end{array}$ & 0,00 & 77,00 & 6,81 & 6,87 \\
\hline Investor Institusional & $\begin{array}{c}183 \\
1\end{array}$ & 0,00 & 0,99 & 0,64 & 0,25 \\
\hline Struktur Modal & $\begin{array}{c}183 \\
1\end{array}$ & $-0,00$ & 22,61 & 0,53 & 0,67 \\
\hline Aset Perseroan* & $\begin{array}{c}183 \\
1\end{array}$ & $9.449,08$ & $351.958 .000,00$ & $11.536 .916,32$ & $26.762 .570,43$ \\
\hline Modal Perseroan* & $\begin{array}{c}183 \\
1\end{array}$ & $37.416 .234,31$ & $195.454 .000,00$ & $5.372 .436,78$ & $13.623 .094,85$ \\
\hline Valid N (listwise) & $\begin{array}{c}183 \\
1\end{array}$ & & & & \\
\hline
\end{tabular}

Tabel 2.

Hasil Uji Statistik Deskriptif

JAA Sumber: Data diolah

4.2 $*=$ Disajikan dalam jutaan rupiah

Kinerja perseroan yang diukur dengan ROA dipengaruhi oleh laba bersih tahun berjalan dan total aset perseroan. Nilai minimum ROA sebesar $-51 \%$ menunjukkan bahwa 
perseroan yaitu Wilton Makmur Indonesia Tbk. memiliki kinerja perseroan yang paling buruk apabila diukur berdasarkan ROA. Kinerja perseroan dengan pengukuran Tobin's $Q$ sendiri sangat dipengaruhi oleh harga saham perseroan dimana nilai $>1$ dianggap overvalued sedangkan nilai $<1$ dianggap undervalued. Perubahan persentase dari Tobin's Q sebagai pengukuran dari kinerja perseroan berdasarkan nilai pasar sangat sensitif terhadap perubahan harga saham yang fluktuatif.

Nilai rata-rata pada direktur eksekutif menunjukkan bahwa porsi direktur eksekutif di dalam dewan direksi perseroan adalah 84\%. Angka tersebut menunjukkan bahwa mayoritas anggota dewan direksi diduduki oleh direktur eksekutif. Di sisi lain, direktur independen memiliki porsi minimum sebesar $0 \%$ dibandingkan dengan total anggota dewan. Hal ini sejalan dengan surat keputusan direksi BEI Nomor: Kep-00183/BEI/12-2018 dimana dinyatakan keberadaan direktur independen sudah tidak diwajibkan lagi sejak akhir tahun 2018. Di saat yang bersamaan, ditunjukkan rata-rata perseroan yang tercatat di BEI memiliki jumlah direktur sebanyak empat atau lima orang termasuk direktur utama dalam dewan direksinya. Dengan rata-rata ukuran dewan sebanyak empat orang, rata-rata jumlah direktur wanita dalam sebuah perseroan hanya sebesar 0,63 alias hampir tidak ada. Hal ini menunjukkan keberadaan direktur wanita dalam perseroan yang terdaftar dalam BEI masih cenderung minim dengan nilai minimum sebanyak nol orang atau tidak ada sama sekali dan maksimum sebanyak lima orang.

Variabel rapat komite audit menunjukkan rata-rata perseroan yang digunakan sebagai sampel melakukan pertemuan sebanyak enam kali dalam setahun. Berdasarkan penelitian Mohamed et al. (2013), rata-rata rapat komite audit sebanyak enam kali sudah terbilang bagus karena menunjukkan fungsi pengawasan yang baik. Nilai standar deviasi sebesar 6,87 menunjukkan jumlah pertemuan komite audit di tiap perseroan berada di angka yang sangat beragam karena kebijakan tata kelola perusahaan yang bervariasi. Kepemilikan investor institusional yang terdapat dalam perseroan yang terdaftar di BEI menunjukkan nilai ratarata kepemilikan investor institusional sebesar 64\%. Hal ini berarti rata-rata keberadaan investor institusional sebagai pemegang saham di perseroan di Indonesia mendominasi. Nilai minimum 0 sebanding dengan kebijakan peraturan BEI yang menyebutkan keberadaan kepemilikan institusional dalam perseroan tidak bersifat wajib.

Struktur Modal diukur melalui leverage yaitu perbandingan antara total liabilitas terhadap total aset perseroan. Berdasarkan Tabel 2 diketahui nilai maksimum dari leverage dimiliki oleh Tiga Pilar Sejahtera Food Tbk dengan tingkat liabilitas perseroan 22,61 kali lebih banyak dari aset perseroan. Nilai tersebut berbanding jauh dengan nilai rata-rata yaitu 53\%. Nilai rata-rata sebesar 53\% menunjukkan rata-rata perseroan lebih memilih untuk menggunakan leverage yang tinggi untuk memiliki sumber modal atau pendanaan dari pihak eksternal.

Sebagai variabel kontrol rata-rata jumlah aset perseroan dari perseroan yang tercatat dalam Bursa Efek Indonesia adalah sebesar 11.536.916.000.000 atau 11 triliun rupiah. Nilai tertinggi dari variabel ini sendiri adalah 351.958.000.000 yang dimiliki oleh Astra International Tbk. sekaligus menjadi perseroan dengan kapitalisasi pasar terbesar ke-enam di Indonesia. Sebagai variabel kontrol kedua, rata-rata dari variabel modal perseroan berada pada angka 5.372.436.000.000 atau bisa dibilang hampir setengah dari rata-rata aset perseroan. Nilai terkecil dari variabel ini sendiri adalah -37.416.234.310.000. Berada di angka minus, berarti modal perusahaan mengalami defisit. 


\section{Uji Outlier}

Uji outlier dilakukan agar hasil dari uji data pada penelitian ini dapat menghasilkan output yang tepat dan handal. Dalam melakukan uji outlier, penelitian ini menggunakan aplikasi SPSS 25 dengan metode SDR. Data dari hasil pengujian ini kemudian akan digunakan untuk melakukan uji hipotesis di aplikasi Eviews. Hasil pengujian outlier menunjukkan terdapat 79 data yang menyimpang dari 1.910 data yang diamati. Data outlier tersebut tidak boleh diikutsertakan dalam analisis selanjutnya sehingga perlu dihapus. Sampel data yang tersisa adalah sebanyak 1.831 sampel setelah dikurangi dengan data outlier tersebut.

\section{Hasil Uji Hipotesis}

Uji $\mathrm{F}$ merupakan tahapan yang dilakukan agar pengaruh simultan dari hubungan antar variabel independen maupun terhadap dependen dapat dikaji. Pada pengujian ini, apabila nilai signifikansi kurang dari dari 0,05, maka dapat diartikan variabel independen dapat mempengeruhi variabel dependen secara simultan dan juga sebaliknya. Berikut adalah hasil uji F dengan variabel dependen ROA dan Tobin's $Q$.

\begin{tabular}{|c|c|c|c|c|}
\hline Variabel Dependen & F-statistic & Prob (F-statistic) & Kesimpulan & \multirow{3}{*}{$\begin{array}{l}\text { Tabel } 3 . \\
\text { Uji F }\end{array}$} \\
\hline ROA & 5,85 & 0,00 & Model dapat digunakan & \\
\hline Tobin's $Q$ & 26,4 & 0,00 & Model dapat digunakan & \\
\hline
\end{tabular}

Sumber : Data diolah

\begin{tabular}{lcccc}
\hline \multirow{2}{*}{ Var. } & \multicolumn{2}{c}{ ROA } & \multicolumn{2}{c}{ Tobin's $\boldsymbol{Q}$} \\
\cline { 2 - 5 } & Coef & Prob. & Coef & Prob. \\
\hline C & 0,44 & 0,08 & 19,51 & 0,00 \\
Direktur Eksekutif & $-0,04$ & 0,80 & $-1,36$ & 0,18 \\
Direktur Independen & 0,03 & 0,86 & $-1,03$ & 0,31 \\
Ukuran Dewan & 0,00 & 0,18 & 0,03 & 0,05 \\
Direktur Wanita & 0,00 & 0,91 & 0,03 & 0,37 \\
Rapat Komite Audit & 0,00 & 0,89 & 0,00 & 0,97 \\
Investor Institusional & 0,01 & 0,77 & 0,09 & 0,54 \\
Struktur Modal & $-0,08$ & 0,00 & 1,03 & 0,00 \\
Aset Perseroan & $-0,01$ & 0,03 & $-0,61$ & 0,00 \\
Modal Perseroan & 0,00 & 0,00 & 0,00 & 0,76 \\
\hline
\end{tabular}

Tabel 4.

Uji t

Sumber: Data diolah 
Sesuai dengan hasil regresi dari tabel diatas, nilai probabilitas dari kinerja perseroan yang diukur dengan ROA maupun Tobin's $Q$ adalah 0,00. Nilai ini sendiri lebih kecil dari 0,05. Demikian dapat disimpulkan variabel direktur eksekutif, direktur independen, ukuran dewan, direktur wanita, komite audit, investor institusional dan struktur modal secara bersama-sama mempengaruhi kinerja perseroan yang diukur dengan ROA maupun Tobin's Q. Berdasarkan hasil uji $\mathrm{F}$ tersebut, dapat disimpulkan variabel independen yang digunakan sudah dinilai tepat dan layak untuk memprediksi kinerja perseroan yang diukur dengan ROA dan Tobin's $Q$.

Dari hasil uji t yang telah dilakukan, diperoleh persamaan regresi untuk model penelitian yaitu:
ROA $=0,44-$ 0,04Dir_Eks + 0,03Dir_Ind + 0,00Ukr_Dew + 0,00Dir_Wan + 0,00Kom_Aud + 0,01Inv_Ins - 0,08Str_Mod $+e$

Variabel direktur eksekutif tidak berpengaruh terhadap ROA karena memiliki nilai probabilitas dibawah 0,05 yaitu 0,80 . Di saat yang bersamaan variabel direktur independen dan ukuran dewan juga tidak memiliki pengaruh yang signifikan terhadap kinerja perseroan yang diukur dengan ROA. Dari tabel tersebut juga ditunjukkan ROA tidak dipengaruhi secara signifikan oleh variabel direktur wanita, rapat komite audit, dan investor institusional. Sedangkan struktur modal terlihat memiliki hubungan signifikan negatif terhadap ROA dengan tingkat probabilitas 0,00 dan koefisien negatif 0,08. Aset perseroan sebagai variabel kontrol berpengaruh signifikan negatif terhadap kinerja perseroan yang diukur dengan ROA. Di sisi lain koefisien dan probabilitas 0,00 menunjukkan modal perseroan memiliki hubungan yang signifikan positif terhadap ROA. Selanjutnya dibawah ini adalah persamaan regresi untuk model penelitian dengan pengukuran variabel kinerja perseroan menggunakan Tobin's $Q$.

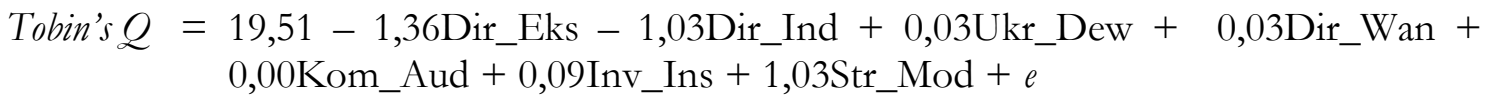

Tabel hasil uji t menunjukkan probabilitas direktur eksekutif dan direktur independen diatas 0,05. Hal ini berarti kedua variabel tersebut tidak berhubungan signifikan terhadap Tobin's Q. Ukuran Dewan sendiri terlihat memiliki hubungan yang signifikan terhadap Tobin's $Q$ dengan koefisien positif. Tiga variabel selanjutnya yaitu direktur wanita, komite audit, dan investor institusional tidak menunjukkan adanya hubungan yang signifikan terhadap Tobin's Q. Hasil yang berbanding terbalik dengan pengukuran ROA ditunjukkan pada variabel struktur modal yang terbukti memiliki hubungan signifikan positif terhadap Tobin's $Q$. Sebagai variabel control, asset perseroan terlihat memiliki koefisien $-0,61$ dan probabilitas dibawah 0,05 yang berarti berpengaruh signifikan negatif terhadap Tobin's Q. Di sisi lain, variabel kontrol modal perseroan tidak memiliki hubungan yang signifikan dengan Tobin's Q.

\section{Hasil Uji Koefisien Determinasi}

Uji koefisien determinasi dilakukan untuk mengkaji kemampuan keseluruhan variabel yang digunakan dapat mempengaruhi satu sama lainnya. Karena memiliki variabel yang beragam, maka penelitian ini berpatokan pada nilai adjusted $\mathrm{R}^{2}$. Angka adjusted $\mathrm{R}^{2}$ dapat diperhatikan pada tabel 5.

Hasil adjusted $\mathrm{R}^{2}$ untuk variabel kinerja perseroan yang diukur dengan ROA dan Tobin's $Q$ masing-masing menunjukkan hasil sebesar 0,51 atau $51 \%$ dan 0,88 atau $88 \%$. Hal ini berarti direktur eksekutif, direktur independen, ukuran dewan, direktur wanita, rapat komite audit, investor institusional dan struktur modal dapat dijelaskan pada variabel kinerja perseroan 
sebesar 51\% untuk pengukuran ROA sedangkan 49\% sisanya dapat dijelaskan variabel lain yang tidak digunakan dalam penelitian ini. Di sisi lain, variabel-variabel independen yang disebutkan sebelumnya juga dapat dijelaskan pada variabel kinerja perseroan sebesar $88 \%$ untuk pengukuran Tobin's $Q$ sedangkan sisanya sebesar $12 \%$ dapat dijelaskan variabel lain yang tidak digunakan dalam penelitian ini.

\begin{tabular}{lcc}
\hline & ROA & Tobin's $\boldsymbol{Q}$ \\
\hline R-squared & 0,61 & 0,88 \\
\hline Adjusted R-squared & 0,51 & 0,84 \\
\hline
\end{tabular}

Tabel 5.

Hasil Uji

Koefisien

Determinasi

Sumber: Data diolah

\section{Pembahasan}

\section{Direktur Eksekutif berpengaruh negatif terhadap kinerja perseroan.}

Berdasarkan hasil uji, direktur eksekutif memiliki pengaruh yang tidak signifikan terhadap kinerja perseroan. Hal ini berarti perseroan yang memiliki ROA di rata-rata memiliki porsi direktur eksekutif yang berbeda-beda pula. Hasil uji hipotesis ini sejalan dengan penelitian yang ditunjukkan Puni \& Anlesinya (2020) yang menyatakan direktur eksekutif atau internal tidak memiliki pengaruh yang signifikan terhadap ROA perseroan.

Porsi direktur eksekutif yang besar maupun kecil dalam dewan direksi sendiri juga tidak mempengaruhi kinerja perseroan yang diukur dengan nilai pasar secara signifikan. Hasil uji data tersebut menunjukkan bahwa keputusan menjual atau membeli saham perseroan bagi investor di pasar tidak begitu dipengaruhi oleh porsi direktur eksekutif dalam dewan direksi perseroan. Hal yang sama juga dikemukakan dalam penelitian $\mathrm{Ng}$ et al. (2020), Narwal \& ذindal (2015), dan Borlea et al. (2017). Dari hasil uji ini dapat disimpulkan hipotesis H1 ditolak.

\section{Direktur Independen berpengaruh positif terhadap kinerja perseroan.}

Direktur independen disimpulkan tidak memiliki pengaruh yang signifikan terhadap ROA perseroan. Hasil dari uji hipotesis ini tidak sama dengan penelitian Masitoh \& Hidayah (2018) serta Puni \& Anlesinya (2020) yang mengemukakan direktur independen berhubungan signifikan negatif terhadap ROA. Di sisi lain terdapat beberapa penelitian yang menyatakan hal yang sama dengan hasil uji ini. Penelitian Puni \& Anlesinya (2020) dan Bashir et al. (2020) menyatakan tidak ada hubungan yang signifikan antara direktur independen dengan ROA dari perseroan tersebut. Dengan kata lain, jumlah direktur independen dalam perseroan belum tentu dapat meningkatkan laba perseroan tersebut. Hasil ini sama dengan hipotesis sebelumnya, yakni direktur eksekutif. Demikian hipotesis tidak terbukti untuk variabel dependen ROA.

Keberadaan direktur independen dalam dewan direksi tidak mempengaruhi kinerja pasar perseroan secara signifikan. Hasil uji ini sendiri gagal membuktikan hipotesis H2. Tetapi di sisi lain, terdapat penelitian-penelitian terdahulu yang telah ada juga menyatakan hal yang sama. Penelitian Vo \& Nguyen (2014), Octavianto \& Widagdo (2012), Ahmed \& Hamdan (2015), dan Veno (2015) menunjukkan bahwa direktur independen tidak berhubungan signifikan dengan kinerja perseroan. Berdasarkan hasil tersebut, dapat disimpulkan

JAA kenaikan dan penurunan harga saham perseroan tidak akan terlalu dipengaruhi oleh porsi keberadaan direktur independen dalam dewan direksi.

\subsection{Ukuran Dewan berpengaruh positif terhadap kinerja perseroan.}

Ukuran dewan dianggap tidak berpengaruh signifikan kepada ROA. Hal ini sekaligus 
membantah hipotesis $\mathrm{H} 3$ karena ini berarti setiap terjadi penambahan atau pengurangan pada anggota dewan, ROA tidak terpengaruh secara signifikan. Pernyataan yang sama juga dikemukakan dalam penelitian Nawaz \& Ahmad (2017), Vo \& Nguyen (2014), dan Sriram (2018). Dimana hasil dari penelitian-penelitian tersebut juga menyimpulkan nilai ROA tidak terpengaruh ukuran dewan direksi suatu perseroan.

Variabel dependen Tobin's $Q$ menunjukkan bahwa perusahaan yang memiliki ukuran dewan yang besar memiliki kinerja saham yang lebih baik secara signifikan. Hal ini berarti terdapat perbedaan yang sejajar antara rata-rata dari Tobin's $Q$ perseroan dengan jumlah anggota dewan direksi. Hasil pengujian ini konsisten dengan hipotesis $\mathrm{H} 3$ dan juga penelitian Veno (2015), PeiZhi \& Ramzan (2020), Detthamrong et al. (2017), Jamal \& Mahmoood (2018), Mohamed et al. (2013), serta Noreen et al. (2018). Dengan kata lain, investor pasar mengapresiasi lebih perseroan yang dioperasikan oleh banyak direksi.

\section{Direktur Wanita berpengaruh positif terhadap kinerja perseroan.}

Direktur wanita tidak berhubungan signifikan kepada ROA. Terdapat pula beberapa penelitian terdahulu yang juga menyatakan hal yang sejajar, diantaranya adalah penelitian Saha \& Kabra (2015) serta Saleh \& Islam (2020). Hal ini berarti tinggi rendahnya laba perseroan tidak begitu disebabkan oleh keberadaan direksi wanita.

Hubungan yang sama juga ditunjukkan dalam hubungan antara direktur wanita dengan Tobin's Q. Hasil uji ini tidak sama dengan hipotesis penelitian yang memprediksi variabel ini dapat memberikan hubungan positif secara signifikan terhadap variabel dependen. Penelitian yang dilakukan Pucheta-Martínez \& Gallego-Álvarez (2020) dan PeiZhi \& Ramzan (2020) menyatakan hasil yang kontradiktif, yakni adanya hubungan signifikan yang positif antara direktur wanita terhadap Tobin's $Q$. Pengaruh yang ditemui dalam penelitian ini sendiri sejajar dengan beberapa penelitian yang juga menyimpulkan keberadaan direktur wanita tidak berpengaruh signifikan kepada Tobin's $Q$. Penelitian-penelitian tersebut adalah penelitian Saha \& Kabra (2015) dan Saleh \& Islam (2020). Demikian dapat disimpulkan sikap positif dan proaktif dari direktur wanita itu sendiri tidak memberi dampak yang signifikan terhadap kinerja perseroan. Hal ini sekaligus membantah argumen yang dinyatakan oleh Terjesen et al. (2016).

\section{Rapat Komite Audit berpengaruh negatif terhadap kinerja perseroan.}

Berdasarkan hasil uji, rapat komite audit menunjukkan hubungannya dengan ROA tergolong tidak signifikan. Hasil ini berbeda terhadap penelitian Noreen et al. (2018) dan Jamal \& Mahmoood (2018) yang menunjukkan frekuensi rapat komite audit berdampak terhadap ROA. Berbeda dengan penelitian lainnya, penelitian Ahmed et al. (2019) dan Detthamrong et al. (2017) menyatakan rapat komite audit mempengaruhi ROA secara tidak signifikan. Hal yang dikemukakan tersebut sejajar dengan hasil pengujian dalam penelitian ini dimana dapat diartikan bahwa frekuensi dari rapat komite audit suatu perseroan tidak akan meningkatkan atau menurunkan laba dari suatu perseroan secara drastis.

Di saat yang bersamaan, variabel rapat komite audit juga tidak berhubungan signifikan terhadap Tobin's $Q$ seperti yang dinyatakan dalam penelitian Ahmed et al. (2019), Detthamrong et al. (2017), serta Jamal \& Mahmoood (2018). Oleh karena itu, dapat disimpulkan nilai dari harga saham yang digunakan sebagai perhitungan dalam rumus Tobin's $Q$ tidak dipengaruhi oleh rapat komite audit perseroan itu sendiri. Demikian hipotesis $\mathrm{H} 5$ tidak terbukti baik untuk variabel dependen yang diukur menggunakan ROA maupun Tobin's $Q$. 


\section{Investor Institusional berpengaruh positif terhadap kinerja perseroan.}

Kehadiran invenstor institusional tidak menunjukkan adanya hubungan yang signifikan terhadap kinerja perseroan. Hasil ini berbeda dengan hipotesis investor institusional berpengaruh signifikan negatif terhadap ROA. Namun hasil regresi ini sejalan dengan hasil dari beberapa penelitian yang telah dilakukan sebelumnya. Penelitian Zeitun (2014), Nazir et al. (2018), Bashir et al. (2020), dan Akbar et al. (2019) juga mengemukakan bahwa investor institusional tidak berhubungan signifikan terhadap kinerja perseroan. Di saat yang bersamaan, peran aktif maupun pasif dari investor institusional dapat dikatakan tidak akan secara signifikan mempengaruhi laba suatu perseroan.

Pengaruh yang sama juga ditunjukkan dalam pengaruh kehadiran investor institusional terhadap kinerja pasar perseroan atau Tobin's $Q$. Hasil ini bertolakbelakang dengan hipotesis H6. Di sisi lain, hasil regresi ini sejalan dengan hasil dari penelitian Alifia \& Sanusi (2021), Nazir et al. (2018), Bashir et al. (2020), dan Akbar et al. (2019). Penelitian-penelitian tersebut juga mengemukakan bahwa investor institusional tidak berhubungan signifikan terhadap kinerja perseroan. Hubungan yang ada ini dapat disimpulkan bahwa investor di pasar tidak mengambil keputusan untuk membeli atau menjual saham perseroan hanya dengan melihat keberadaan investor insitusional dalam perseroan tersebut.

\section{Struktur Modal berpengaruh negatif terhadap kinerja perseroan.}

Variabel struktur modal pada penelitian ini ditunjukkan terdapat hubungan negatif yang signifikan kepada ROA. Hasil uji tersebut selaras dengan hipotesis penelitian yaitu struktur modal berpengaruh signifikan negatif terhadap kinerja perseroan. Hasil yang sama ditunjukkan dalam hasil penelitian Abata et al. (2017), Abdur Rouf (2015), dan Kipesha \& James (2014). Kesimpulan dari penelitian-penelitian tersebut juga menginterpretasikan bahwa tingginya suatu ROA perseroan tidak diikuti oleh tingginya liabilitas suatu perseroan dibanding asetnya.

Berbeda dengan ROA, variabel struktur modal terlihat memberikan pengaruh yang bertolak belakang kepada Tobin's $Q$ atau nilai pasar perseroan. Hubungan dari kedua variabel ini tidak sejalan dengan hipotesis H7. Hasil ini bertolak belakang dengan penelitian Bahri (2018) yang menyatakan investor cenderung menghindari perseroan yang memiliki leverage tinggi sehingga berdampak pada penurunan harga saham. Di sisi lain, hasil ini konsisten dengan penelitian Abata \& Migiro (2019) dimana hasil penelitian tersebut menunjukkan kinerja pasar perseroan yang diukur dengan nilai pasar (nilai saham) akan meningkat apabila leverage perseroaan bernilai tinggi atau eksrim. Demikian dapat disimpulkan tinggi rendahnya leverage dari suatu perseroan dapat mempengaruhi kinerja pasar perseroan itu sendiri secara sejajar.

\section{SIMPULAN}

Berdasarkan pengujian dan analisis yang telah dibahas pada bab-bab sebelumnya, dapat disimpulkan bahwa perseroan dengan nilai ROA dan Tobin's $Q$ di rata-rata memiliki porsi direktur eksekutif, independen, dan wanita yang berbeda-beda pula. Besar kecilnya porsi direktur-direktur tersebut dalam dewan direksi tidak mempengaruhi kinerja perseroan berdasarkan nilai buku maupun pasar. Di sisi lain, perseroan dengan nilai Tobin's $Q$ yang tinggi cenderung dijalankan oleh dewan direksi yang berukuran besar. Intensitas rapat komite audit dan keberadaan investor institusional sendiri tidak mempengaruhi kinerja perseroan non finansial yang terdaftar di BEI. Dapat disimpulkan pula semakin banyaknya pendanaan dari pihak eksternal, ROA perseroan dapat menurun secara signifikan. Dengan kata lain para pihak pengambil keputusan berusaha mempertahankan leverage pada level 
yang rendah untuk menjaga keamanan dan meningkatkan kinerja perseroan seefektif dan seefisien mungkin. Berbanding terbalik dengan ROA, investor di pasar cenderung mengapresiasi lebih perseroan yang memiliki leverage tinggi namun diikuti dengan kinerja buku yang menjanjikan karena adanya hubungan yang signifikan positif antara struktur modal dengan Tobin's $Q$.

Keterbatasan pada penelitian ini terbatas pada sampel yang terdiri atas 41 perusahaan yang dikeluarkan karena laporan tahunan dan keuangan yang belum dipublikasi atau tidak lengkap serta telah pailit. Penelitian ini menggunakan perusahaan sektor nonfinansial, demikian penelitian selanjutnya disarankan dapat menggunakan perusahaan di sektor lain supaya hasil penelitian dapat dibandingkan. Implikasi penelitian ini adalah agar dapat dijadikan sebagai pedoman perseroan mengenai informasi-informasi pengaruh penerapan tata kelola perusahaan yang baik dan struktur modal terhadap kinerja perseroan serta membantu investor pasar dalam mengambil keputusan dan dapat memperluas wawasan dan literatur pada ilmu pengetahuan.

\section{DAFTAR PUSTAKA}

Abata, M. A., \& Migiro, S. O. (2019). Capital Structure and Firm Performance in NigerianListed Companies. Journal of Chemical Information and Modeling, 53, 1689-1699. https://doi.org/10.1017/CBO9781107415324.004

Abata, M. A., Oseko Migiro, S., Akande, J. O., \& Layton, R. (2017). Does Capital Structure Impact on the Performance of South African Listed Firms? Acta Universitatis Danubius, 13, 334-350.

Abdur Rouf, M. (2015). Capital Structure and Firm Performance of Listed Non-Financial Companies in Bangladesh. The International Journal of Applied Economics and Finance, 9, 25-32. https://doi.org/10.3923/ijaef.2015.25.32

Ahmed, E., \& Hamdan, A. (2015). The impact of corporate governance on market capitalization: Evidence from Bahrain Bourse. Corporate Ownership and Control, 11, 121-130. https://doi.org/10.22495/cocv13i3p11

Ahmed, F., Talreja, S., \& Kashif, M. (2019). Effects of Corporate Governance and Capital Structure on Firms' Performance: Evidence from Major Sectors of Pakistan. Indonesian Capital Market Review, 10, 90-104. https://doi.org/10.21002/icmr.v10i2.10873

Ahmed, R., \& Bhuyan, R. (2020). Capital Structure and Firm Performance in Australian Service Sector Firms: A Panel Data Analysis. Journal of Risk and Financial Management, 13, 214. https://doi.org/10.3390/jrfm13090214

Aini, Y. N., Haryanti, A. D., \& Trianti, K. (2021). ANALISIS KINERJA INDUSTRI ROKOK YANG TERDAFTAR DI BURSA EFEK INDONESIA DENGAN PENDEKATAN RASIO PROFITABILITAS. Jurnal Akademi Akuntansi, 4(1), 5658. https://doi.org/10.22219/jaa.v4i1.15474

Akbar, M., Hussain, S., Ahmad, T., \& Hassan, S. (2019). Corporate governance and firm performance in Pakistan: Dynamic panel estimation. Abasyn Journal of Social Sciences, 12, 213-230. https://doi.org/10.34091/ajss.12.2.02

Akingunola, R. O., Olawale, L. S., \& Olaniyan, J. D. (2018). Capital structure decision and firm perforamnce: Evidence from non-financial firms in Nigeria. Acta Universitatis Danubius. EEconomica, 13, 4136-4373. 
Al-ahdal, W. M., Alsamhi, M. H., Tabash, M. I., \& Farhan, N. H. S. (2020). The impact of corporate governance on financial performance of Indian and GCC listed firms: An empirical investigation. Research in International Business and Finance, 51, 101083. https://doi.org/10.1016/i.ribaf.2019.101083

Alifia, S., \& Sanusi, F. (2021). THE INFLUENCE OF INSTITUTIONAL OWNERSHIP ON CORPORATE VALUES WITH DEBT EQUITY RATIO AND AND PROFITABILITY AS INTERVENING VARIABLES. Jurnal Akademi Akuntansi, 4(1), 1-9. https://doi.org/10.30537/sjcms.v4i1

Anderson, R. C., \& Reeb, D. M. (2003). American Finance Association Founding-Family Ownership and Firm Performance : Evidence from the S \& P 500 Authors ( s ): Ronald C. Anderson and David M . Reeb Published by : Wiley for the American Finance Association Stable URL : http://www.jstor.org/sta. The Journal of Finance, 58, 1301-1328.

Azeez, D. A. A. (2015). Corporate Governance and Firm Performance: Evidence from Sri Lanka. Journal of Finance and Bank Management, 3, 180-189. https://doi.org/10.15640/ifbm.v3n1a16

Bahri, S. (2018). PENGARUH KINERJA KEUANGAN TERHADAP HARGA SAHAM (Studi Pada Perusahaan Sub Sektor Makanan Dan Minuman Yang Terdaftar Di Bursa Efek Indonesia). Fakultas ekonomi univeritas islam, 9(1), 1-21. http://dx.doi.org/10.1053/i.gastro.2014.05.023\%0Ahttps://doi.org/10.1016/i.gie. 2018.04.013\%0Ahttp://www.ncbi.nlm.nih.gov/pubmed/29451164\%0Ahttp://ww w.pubmedcentral.nih.gov/articlerender.fcgi?artid=PMC5838726\%250Ahttp://dx.d oi.org/10.1016/j.gie.2013.07.022

Bashir, Z., Bhatti, G. A., \& Javed, A. (2020). Corporate governance and capital structure as driving force for financial performance : Evidence from non-financial listed companies in Pakistan. Business Review, 15.

Bassem, B. S. (2009). Governance and Performance of Microfinance Institutions in Mediterranean Countries. Journal of Business Economics and Management, 10(1), 31-43. https://doi.org/10.3846/1611-1699.2009.10.31-43

Birken, E. G., \& Curry, B. (2021). Understanding Return On Assets (ROA). Forbes Advisor. https://www.forbes.com/advisor/investing/roa-return-on-assets/

Bisnis. (2015). Rating Tata Kelola Perusabaan di Indonesia Terendah di Asean - Market Bisnis.com.

Borlea, S. N., Achim, M. V., \& Mare, C. (2017). Board characteristics and firm performances in emerging economies. Lessons from Romania. Economic ResearchEkonomska Istrazivanja 30, 55-75. https://doi.org/10.1080/1331677X.2017.1291359

Brown, L. D., \& Caylor, M. L. (2006). Corporate governance and firm valuation. Journal of Accounting and Public Policy, 25(4), 409-434. https://doi.org/10.1016/j.jaccpubpol.2006.05.005

Chabachib, M., Irawan, B. P., Hersugondo, H., Hidayat, R., \& Pamnngkas, I. D. (2020). Corporate governance, firm performance and capital structure: Evidence from Indonesia. Research in World Economy, 11, 48-55. https://doi.org/10.5430/rwe.v11n1p48

CNN. (2019). Buntut Kasus Karen, Pemerintah akan Benabi Tata Kelola BUMN. 
Darko, J., Aribi, Z. A., \& Uzonwanne, G. C. (2016). Corporate governance: the impact of director and board structure, ownership structure and corporate control on the performance of listed companies on the Ghana stock exchange. Corporate Governance (Bingley), 16, 259-277. https://doi.org/10.1108/CG-11-2014-0133

David, P., Kochhar, R., \& Levitas, E. (1989). Academy of Manttgement loumal igS8. 41, 20-20.

Detthamrong, U., Chancharat, N., \& Vithessonthi, C. (2017). Corporate governance, capital structure and firm performance: Evidence from Thailand. Research in International Business and Finance, 42, 689-709. https://doi.org/10.1016/i.ribaf.2017.07.011

Dewi, N. A., \& Gustyana, T. T. (2020). Pengaruh Corporate Governance Terhadap Nilai Perusahaan dengan Kinerja Keuangan Sebagai Variabel Moderasi. Fakultas ekonomi univeritas islam, 11(1), 133-157.

Fuzi, S. F. S., Halim, S. A. A., \& Julizaerma, M. K. (2016). Board Independence and Firm Performance. Procedia Economics and Finance, 37, 460-465. https://doi.org/10.1016/s2212-5671(16)30152-6

Ganiyu, R. A., Barbara, O. A., \& Paul, O. O. (2018). Trends in Business Performance Measurement: A literature Analysis. International Journal of Social Sciences and Humanities Reviews, 8, 151-160.

Habib, M. A. (2016). Relationship Between Corporate Governance and Firm Performance: A Case Study In Bangladesh. 3218, 1120.

Hakim, M. Z., \& Naelufar, Y. (2020). Analysis of Profit Growth, Profitability, Capital Structure, Liquidity and Company Size of Profit Quality. Jurnal Akademi Akuntansi, 3(1), 12. https://doi.org/10.22219/jaa.v3i1.10348

Hidayat, A. A., \& Utama, S. (2015). Board Characteristics and Firm Performance: Evidence from Indonesia. International Research Journal of Business Studies, 8, 137-154. https://doi.org/10.21632/iribs.8.3.137-154

Hundal, S., Eskola, A., \& Lyulyu, S. (2020). The Impact of Capital Structure on Firm Performance and Risk in Finland. Eurasian Economic Perspectives, 43-67. https://doi.org/10.1007/978-3-030-48531-3 4 (Eurasian Studies in Business and Economics)

Jamal, S., \& Mahmoood, D. W. (2018). Impact of Corporate Governance \& Capital Structure on Firm Financial Performance : Evidence from Listed Cement Sector of Pakistan. 48, 6-16.

Kipesha, E. F., \& James, J. M. (2014). Capital Structure and Firm Performance : Evidences from Commercial Banks in Tanzania. Research Journal of Finance and Accounting, 5, 168-179.

Kyere, M., \& Ausloos, M. (2020). Corporate governance and firms financial performance in the United Kingdom. International Journal of Finance and Economics, 1-15. https://doi.org/10.1002/ijfe.1883

Liputan6. (2018). Penerapan Tata Kelola Baik Perusahaan Indonesia Tertinggal di ASEAN - Bisnis Liputan6.com. 
Majid, S. R., Titisari, K. H., \& Siti, N. (2020). Pengaruh Profitabilitas, Leverage, Komite Audit Dan Dewan Direksi Terhadap Nilai Perusahaan. Fakultas ekonomi univeritas islam, 11(1), 1-18.

Masitoh, N. S., \& Hidayah, N. (2018). PENGARUH PENERAPAN GOOD CORPORATE GOVERNANCE TERHADAP KINERJA PERUSAHAAN (Studi Empirik Pada Perusahaan Perbankan di BEI tahun 2014 - 2016). TEKUN: Jurnal Telaah Akuntansi dan Bisnis, 9, 49-59. https://doi.org/10.22441/tekun.v8i1.2596

Mohamed, E. K. A., Basuony, M. A., \& Badawi, A. A. (2013). The impact of corporate governance on firm performance in Egyptian listed companies. Corporate Ownership and Control, 11, 691-705. https://doi.org/10.22495/cocv11i1c7art6

Muhammad, H., Shah, B., \& Islam, Z. u. (2014). The Impact of Capital Structure on Firm Performance: Evidence from Pakistan. Journal of Industrial Distribution \& Business, 5, 13-20. https://doi.org/10.13106/jidb.2014.vol5.no2.13.

Munir, Q. (2016). Financial and Banking Crisis Prediction through Early Warning SystemsNo Title. IGI Global. https://doi.org/10.4018/978-1-4666-9484-2

Narwal, K., \& Jindal, S. (2015). The Impact of Corporate Governance on the Profitability: An Empirical Study of Indian Textile Industry. International Journal of Research in Management, Science \& Technology, 3, 81-85.

Nawaz, K., \& Ahmad, N. (2017). The effect of corporate governance and capital structure on firms' performance: Investigation on petroleum sector in Pakistan. Journal of Independent Studies and Research-Management, Social Sciences and Economics, 15(1), 51-67. https://doi.org/10.31384/jisrmsse/2017.15.1.4

Nazir, M. U., Khan, M., \& Ather, M. H. (2018). Corporate Governance and Firm Performance: Empirical Evidence from Pakistan \& India Author's. International Journal Of Agriculture And Biological Sciences. https://doi.org/10.18488/journal.aefr.2018.812.1415.1421

Ng, D. C. Y., Lau, T. C., Abdul Rahim, F., \& Shanmugaretnam, S. (2020). The Impact of Board Characteristics on Firm Performance: A Post-MCCG2012 investigation. Environment-Behaviour Proceedings Journal, 5, 31-37. https://doi.org/10.21834/ebpj.v5isi1.2293

Nguyen, T. H., \& Nguyen, H. A. (2020). Capital structure and firm performance of nonfinancial listed companies: Cross-sector empirical evidences from Vietnam. Growing Science, 6, 137-150. https://doi.org/10.5267/j.ac.2019.11.002

Noreen, S., Hafiz, Khan, H., \& Majeed, F. (2018). Corporate Governance on Firm's Financial Performance: Evidence from Pakistan. International Journal of Case Studies, 7, 28-36.

Nyamongo, E. M., \& Temesgen, K. (2013). The effect of governance on performance of commercial banks in Kenya: A panel study. Corporate Governance (Bingley), 13, 236248. https://doi.org/10.1108/CG-12-2010-0107

Octavianto, D., \& Widagdo, K. (2012). Pengaruh Good Corporate Governance Terhadap Kinerja Keuangan. Accounting Analysis Journal, 1, 1-9. https://doi.org/10.15294/aaj.v1i2.655 
OJK. (2014). Peraturan Otoritas Jasa Kenangan Nomor 33/ POJK. 04/2014 tentang Direksi dan Dewan Komisaris Emiten atau Perusahaan Publik.

PeiZhi, W., \& Ramzan, M. (2020). Do corporate governance structure and capital structure matter for the performance of the firms? An empirical testing with the contemplation of outliers. PLOS ONE, 15, 1-25. https://doi.org/10.1371/journal.pone.0229157

Pucheta-Martínez, M. C., \& Gallego-Álvarez, I. (2020). Do board characteristics drive firm performance? An international perspective. Review of Managerial Science, 14, 12511297. https://doi.org/10.1007/s11846-019-00330-x

Puni, A., \& Anlesinya, A. (2020). Corporate governance mechanisms and firm performance in a developing country. International Journal of Law and Management, 62, 147-169. https://doi.org/10.1108/IJLMA-03-2019-0076

Qolbi, N. (2021). Rasio kas Sritex (SRIL) mengkhawatirkan, analis sarankan divestasi untuk bayar utang.

Ramadan, G. R., Prasetyo, O. F., Mujaddid, A., Masyudi, A. R., Mahdi, R. A., Junior, K. L., \& Putra, F. Z. (2021). BOARD OF DIRECTORS GENDER DIVERSITY AND REAL EARNINGS MANAGEMENT DOES FEMALE BOARD OF DIRECTOR MATTER. Jurnal Reviu Akuntansi dan Kenangan, 11(2), 306-320. https://doi.org/10.22219/jrak.v11i2.15915

Rehman, K. U., \& Sadat, M. (2013). A Research towards the Examination of Relationship Organizational Commitment and Job Satisfaction of Academics. Eurasian Journal of Business and Management, 1, 44-57.

Ryff, C. D. (2017). Eudaimonic well-being, inequality, and health: Recent findings and future directions. International Review of Economics, 64, 159-178. https://doi.org/10.1007/s12232-017-0277-4

Saha, R., \& Kabra, K. C. (2015). Does corporate governance influence firm performance? Evidence from India. Economics and Business Review, 1.

Saleh, M. W. A., \& Islam, M. A. (2020). Does Board Characteristics Enhance Firm Performance? Evidence from Palestinian Listed Companies. International Journal of Multidisciplinary Sciences and Advanced Technology, 1, 84-95.

San, O. T., Theng, L. Y., \& Heng, T. B. (2011). A comparison on efficiency of domestic and foreign banks in Malaysia: A DEA approach. Business Management Dynamics, 1, 33-49.

Shakir, R. (2008). Board Size, Executive Directors and Property Firm Performance in Malaysia. Pacific Rim Property Research Journal, 14, 66-80. https://doi.org/10.1080/14445921.2008.11104248

Sinambela, L. P. (2020). PENELITIAN KUANTITATIF Suatu Pengantar. Prismakom, 17(1), 21-36.

Sriram, M. (2018). Board characteristics and firm performance - A study of S\&P BSE Sensex in India. Afro-Asian Journal of Finance and Accounting, 8, 336-349. https://doi.org/10.1504/AAJFA.2018.093482 
Taouab, O., \& Issor, Z. (2019). Firm Performance: Definition and Measurement Models.

$\begin{array}{lllll}\begin{array}{l}\text { European Scientific Journal } \\ \text { https://doi.org/10.19044/esi.2019.v15n1p93 }\end{array} & \text { ESJ, } & \text { 15, } & \text { 93-106. }\end{array}$

Terjesen, S., Couto, E. B., \& Francisco, P. M. (2016). Does the presence of independent and female directors impact firm performance? A multi-country study of board diversity. Journal of Management and Governance, 20, 447-483. https://doi.org/10.1007/s10997-014-9307-8

Triana, \& Asri, M. (2017). the Impact of Female Directors on Firm Performance: Evidence From Indonesia. Journal of Indonesian Economy and Business, 31, 19. https://doi.org/10.22146/jieb.21994

Tribunnews. (2020). 7 Skandal Korupsi di Indonesia dengan Kerugian Terbesar, Garong Duit Negara Hingga Rp 13,7 Triliun - TribunStyle.com.

UKEssays. (2018). What Might We Mean By Firm Performance.

Ullah, M., Afgan, N., \& Afridi, S. A. (2019). Effects of Corporate Governance on Capital Structure and Financial Performance: Empirical Evidence from Listed Cement Corporations in Pakistan. Global Social Sciences Review, IV(III), 197-205. https://doi.org/10.31703/gssr.2019(IV-III).25

Ullah, M., Nouman, A., \& Afridi, S. A. (2019). Effects of corporate governance on capital structure: Empirical evidence from Pakistan. Global Social Sciences Review (GSSR), 4. https://doi.org/10.1108/14720701211275569

Utami, N. (2020). Analysis of the Influences of Dividend Payout Ratio, Return on Equity, Growth and Firm Size on Stock Value With Leverage As Mediating Variable. Jurnal Akademi Akuntansi, 3(1), 44. https://doi.org/10.22219/jaa.v3i1.11501

Veno, A. (2015). Pengaruh Corporate Governance Terhadap Kinerja Perusahaan pada Perusahaan Manufaktur Go Public. Jurnal Manajemen dan Bisnis, 19. https://doi.org/10.20473/jeba.v28i12018.57-73

Vo, D. H., \& Nguyen, T. M. (2014). The Impact of Corporate Governance on Firm Performance: Empirical Study in Vietnam. International Journal of Economics and Finance, 6, 1-13. https://doi.org/10.5539/ijef.v6n6p1

Wareza, M. (2021). Bosnya Digugat PKPU, Utang Jatub Tempo Sritex Nyaris Rp 10 T.

Warrad, L., \& Khaddam, L. (2020). The effect of corporate governance characteristics on the performance of jordanian banks. Accounting, 6, 117-126. https://doi.org/10.5267/j.ac.2019.12.001

Yuanjaya, P. (2019). Sengkarut Tata Kelola BUMN Kita.

Zeitun, R. (2014). Corporate Governance, Capital Structure and Corporate Performance: Evidence from GCC Countries. Review of Middle East Economics and Finance, 10, 7596. https://doi.org/10.1515/rmeef-2012-0028 